\title{
Freezing methods affect the characteristics of large yellow croaker (Pseudosciaena crocea): use of cryogenic freezing for long-term storage
}

\author{
Hoa Thanh TRUONGHUYNH ${ }^{1}$ (D), Baoguo $\mathrm{LI}^{1 *}$, Heng ZHU², Quanyou GUO³ ${ }^{3}$, Song $\mathrm{LI}^{1}$
}

\begin{abstract}
Large yellow croaker (Pseudosciaena crocea) is the main coastal economic fish in China. After harvesting, the fish is rarely traded as the fresh product, but usually held in cold storage. Therefore, it is important to understand the quality changes occurring during preservation. In this study, freshly collected fishes were frozen by cryogenic (cabinet liquid nitrogen freezer at $-40,-60$ and $-80^{\circ} \mathrm{C}$ ) and forced convection (ultra-low temperature freezer at $-40{ }^{\circ} \mathrm{C}$ ) freezing and stored at $-18{ }^{\circ} \mathrm{C}$ for 6 months. Drip loss, relative moisture loss (RML), water holding capacity (WHC), color and texture of frozen fish were evaluated. The results showed that forced convection freezing had significantly higher drip loss and RML values compared to cryogenic freezing. WHC decreased dramatically irrespective of freezing methods employed. Cryogenic freezing at -60 and $-80^{\circ} \mathrm{C}$ had the highest yellowness values during storage; but the highest springiness, gumminess and shear force values were obtained only at $-60^{\circ} \mathrm{C}$. We conclude that cryogenic freezing at $-60{ }^{\circ} \mathrm{C}$ is appropriate for long-term storage of large yellow croaker.
\end{abstract}

Keywords: freezing rate; freezing temperature; drip loss; moisture; fish quality.

Practical Application: Cryogenic freezing at $-60^{\circ} \mathrm{C}$ is suitable for large yellow croaker preservation longer than 6 months.

\section{Introduction}

Large yellow croaker (Pseudosciaena crocea) is a delicious and tender-flesh quality marine fish. According to China Fishery Statistical Yearbook, the aquaculture production of large yellow croaker of the whole nation in 2017 was 165,496 tons (Guo \& Zhao, 2017), thus making it one of the commercially important marine fish species of the country (Liu et al., 2008). In most cases, freshly collected fish is held in cold storage until supplied to the consumers. Therefore, storage of fish between catching and entering supply chain is imperative.

Freezing is becoming a useful technique to preserve fish and other seafood products without significant loss in quality, because it increases the shelf-life of the product and creates the accessibility of stored products over long distances (Leygonie et al., 2012; Makarios-Laham \& Lee, 1993; Tolstorebrov et al., 2016). However, if appropriate techniques were not employed, biochemical reactions (microbiological and enzymatic activities) are not completely halted, thus samples will continue to deteriorate with lipid oxidation, protein denaturation, etc. affecting the quality of frozen products. As such, these stored products will become unacceptable for consumption (Leygonie et al., 2012).

Improper freezing techniques could result in significant damage to stored fish products. Indeed, previous studies have demonstrated that freezing rate affects the size, distribution and location of ice crystals formed in frozen samples, consequently leading to the muscle tissues damage resulting in weight loss and quality changes of frozen food products (Añón \& Calvelo, 1980; Kono et al., 2017; Wagner \& Anon, 1985). Moreover, freezing rates are affected by freezing methods, air speed, operating temperature, and products' properties (Espinoza Rodezno et al., 2013). Therefore, different freezing methods have been invented to minimize the damage induced by ice crystal formation, thereby satisfying the demand of variety types of food products.

One technique that is gaining momentum in the recent past is cryogenic freezing, i.e. using cryogenic fluid like liquid nitrogen and/or carbon dioxide with rapid freezing rates. Cryogenic freezing has been reported to have higher muscle integrity (Chen \& Pan, 1997; Pan \& Yeh, 1993), and improve texture, color and sensory properties of the frozen food products (Agnelli \& Mascheroni, 2002; Qian et al., 2018; Streeter \& Spencer, 1973). However, the usefulness of cryogenic freezing is still debated because the stored fish and/or seafood products suffered significant quality loss in some studies (Chen \& Pan, 1997; Jiang et al., 2018; Pan \& Yeh, 1993). For example, the shelf-life of grass shrimp (Penaeus monodon) frozen with liquid nitrogen and subsequently stored at $-20^{\circ} \mathrm{C}$ was less than one month (Pan \& Yeh, 1993). Likewise, the shelf-life of tilapia (Oreochromis SP) frozen with liquid nitrogen and stored at $-20^{\circ} \mathrm{C}$ was only predicted to be 2.7 months (Chen \& Pan, 1997). Furthermore, cryogenic freezing showed no improvement in maintaining microstructure of northern snakehead (Channa argus) fillets, although it reduced the $\mathrm{pH}$ decrease and salt-soluble protein content (Jiang et al., 2018).

Whilst the search for proper storage of fishes continues, there is little information concerning the effect of freezing methods and storage duration on large yellow croaker. The aim of this 
paper is to investigate the feasibility of storing large yellow croaker using cryogenic freezing at different temperatures and forced convection freezing. To recommend the appropriate method for storage, we compared these two freezing techniques, stored fishes for 6 months and studied the freezing loss, drip loss, relative moisture loss, water holding capacity, color and texture of large yellow croaker.

\section{Materials and methods}

\subsection{Fish materials}

Large yellow croaker was purchased at Ningde Jingli Aquatic Products Co., Ltd. (Fujian Province, China) and transported to University of Shanghai for Science and Technology, Shanghai, China within 12 hours in iced boxes. Immediately after arrival in the lab (108 fishes in total), fish length and weight were determined. Fish samples were wrapped in plastic bags and stored at $0{ }^{\circ} \mathrm{C}$ in the fridge for 3 hours before used in further experiments.

\subsection{Freezing procedures}

Forced convection freezing (FCF) was conducted by forced wind freezing at $-40^{\circ} \mathrm{C}$ in a vertical ultra-low temperature freezer (DW-86L626, Haier Qingdao Special Electrical Appliance Co., Ltd., China).

For cryogenic freezing, three different freezing temperatures at $-40,-60$, and $-80^{\circ} \mathrm{C}$ were applied independently in a cabinet cryogenic freezer (Praxair Investment Co., Ltd, Shanghai, China). The cryogenic freezer was equipped with one chamber $(100 \times 100 \times 90 \mathrm{~cm})$ and stainless steel shelving system holding four master trays at four levels (Figure 1). The shelving unit was of $48 \times 60 \times 8 \mathrm{~cm}$ dimension to accommodate fish trays. Liquid nitrogen was injected through transfer line and sprayer nozzle into the freezing chamber from a pressurized tank (Dura-Cyl 160 MP, Praxair Co., Ltd., Shanghai, China). The pressurized tank had the storage of $110 \mathrm{~kg}$ of boiling liquid nitrogen and monitored by the tank-fitted relief valve. The fan/ suction ventilator was located in front of the sprayer nozzle and stimulated the circulation of the cooling medium throughout the chamber. A computer control algorithm (West 6100, Shenzhen Yitahua Electronics Development Co., Ltd, China) was attributed to regulate and control the injection temperature of nitrogen into the chamber via a solenoid valve.

After setting the freezing temperature in the procedure, the tank valve was opened to the pressure of $2.5 \mathrm{MPa}$. Liquid nitrogen passed through the solenoid valve to the spray nozzle; the chamber environment was cooled to the freezing temperature. Fish samples were then put inside. Once the chamber temperature was lower than the predetermined temperature, the solenoid valve would be automatically closed; in contrast, it would be opened to atomize the liquid nitrogen and maintain the freezing temperature in the chamber. As the freezing time increased, the low-temperature nitrogen in the chamber accumulated and increased the pressure; the internal excess nitrogen would be discharged by the help of the fan and pressure relief pump.

Twenty-seven fish per batch were frozen for each freezing treatment. A thermocouple type K (Yokogawa TX10 series, Yokogawa Test \& Measurement (Shanghai) Co., Ltd, China) was inserted into the geometric dorsal center of fish to monitor the temperature changes in samples. All freezing treatments were finished as the fish core temperature reached $-20 \pm 0.5^{\circ} \mathrm{C}$. Fish samples were vacuum-packaged in polyethylene bags and transferred to a cold storage refrigerator (BD/BC-518, Fujian Chuanglong Electric Appliance Technology Co., Ltd., China), and stored at $-18^{\circ} \mathrm{C}$ for 6 months.

Quality analyses were performed for samples after 0 (immediately after freezing treatments), 3 and 6 months of storage. Before analysis, frozen samples were thawed under flowing tap water for one hour until the core temperature of large yellow croaker reached $0{ }^{\circ} \mathrm{C}$. Upon thawing, skin color measurements were conducted. Then, fish skin was peeled, and dorsal muscle was taken for further experiments.

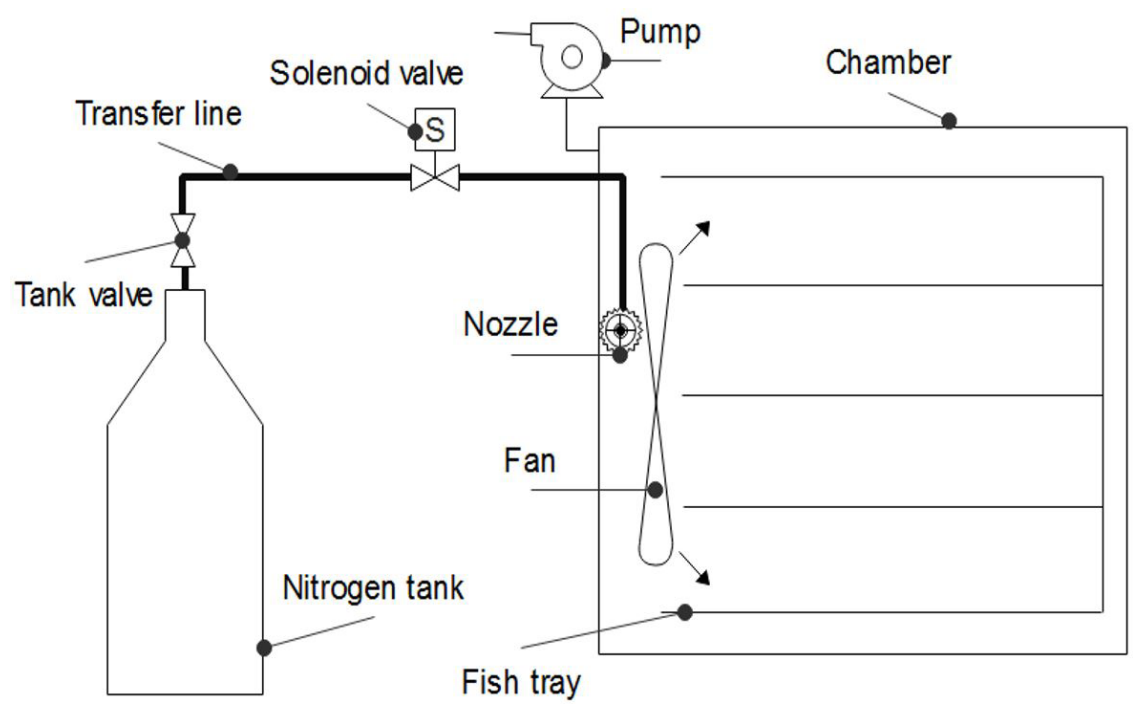

Figure 1. Diagram of liquid nitrogen cabinet freezer. 


\subsection{Freezing rate, freezing loss and drip loss}

Freezing rate and drip loss were calculated as given in the following Equations 1 and 2.

Freezing rate $\left({ }^{\circ} \mathrm{C} / \mathrm{h}\right)=\frac{\begin{array}{c}\text { initial temperature of entire fish }- \\ \text { final freezing temperature }\end{array}}{\text { total freezing time }}$

Drip loss $(\%)=\frac{\text { weight of frozen sample }- \text { weight of thawed sample }}{\text { weight of frozen sample }} \times 100$

\subsection{Moisture content and relative moisture loss}

Moisture content was determined by drying a $2 \mathrm{~g}$ minced fish flesh at $110^{\circ} \mathrm{C}$ until the dry weight reached a constant level in a moisture analyzer (Adam Equipment, USA), as proposed by the official method of Chinese standard GB 5009.3-2016 (China National Standards, 2016). Relative moisture loss was calculated using Equation 3.

Relative moisture loss $(\%)=\frac{\begin{array}{c}\text { moisture content of unfrozen sample }- \\ \text { moisture content of frozen sample }\end{array}}{\text { moisture content of unfrozen sample }} \times 100$

\subsection{Water holding capacity}

Water holding capacity of fish muscle (\%) was determined following the methods described by Luan et al. (2018) with modification. In brief, $3 \mathrm{~g}$ of minced fish samples were put into 3 centrifugation tubes and spun at $3000 \mathrm{rpm}$ for $20 \mathrm{~min}$ at $4{ }^{\circ} \mathrm{C}$. After centrifuging, the samples were removed from the tubes and the difference in weights were calculated. The difference in weights are expressed on a percentage of fresh weight basis.

\subsection{Color measurement}

Color of samples was assessed by Chroma Meter CR-400 (Konica Minolta, Inc., Japan) at the fish abdominal skin (the center point between the ventral fin and the anal fin at abdomen section). CIE $L^{\star}, a^{*}, b^{*}$ values were measured. $L^{*}$ describes the lightness of the sample $\left(L^{*}>0\right), a^{*}$ intensity in redness $\left(a^{\star}>0\right)$, and $b^{\star}$ intensity in yellowness $\left(b^{\star}>0\right)$. Color measurement was conducted by five replicates for each group.

\subsection{Texture}

Fish dorsal muscle was cut into $20 \times 20 \times 10 \mathrm{~mm}$ pieces. Textural values of fish from all groups were measured using a TMS-Pro Texture Analyzer (Food Technology Corporation, USA) with the Texture Lab Pro (TL-Pro) software package. A flat-ended cylindrical plunger $(1 / 2$ " in diameter was pressed into the fillets perpendicular to the muscle fibers at a constant speed of $5 \mathrm{mms}^{-1}$ until it reached $60 \%$ of the fillet height. The maximum force to cut the dorsal muscle was recorded as the shear force $(\mathrm{N})$. All the measurements were performed by nine muscle pieces per replicate.

\subsection{Statistical analysis}

The statistical significance of observed differences among treatment means was evaluated using SPSS statistics software version 20.0 (IBM Analytics, US). Significant differences between convection and cryogenic freezing were analyzed using analysis of variance (ANOVA) with a LSD post-hoc test at a 95\% confidence level $(P<0.05)$.

\section{Results and discussion}

\subsection{Freezing time, freezing rate and drip loss}

Fish storage is imperative and our current understanding suggests that the quality of the frozen fish is affected by temperature/rate at which the samples frozen and stored (Añón \& Calvelo, 1980; Hiner et al., 1945; Mørkøre \& Lilleholt, 2007). Freezing temperature/rate can affect the evaporation of water from the products' surface when freezing (Campañone et al., 2001; Rao \& Novak, 1977). When a product is frozen rapidly under lower freezing temperature, the evaporative loss will be minimal (Rao \& Novak, 1977). The average length and weight of fishes used in the present study were $30.90 \pm 0.87 \mathrm{~cm}$ and $364.30 \pm 23.76 \mathrm{~g}$, respectively. Our freezing results indicate that the freezing time and rate of cryogenic freezing at $-40,-60$, and $-80^{\circ} \mathrm{C}$ were $20,15,10 \mathrm{~min}$ and $120,240,480{ }^{\circ} \mathrm{C} \mathrm{h}{ }^{-1}$, respectively; meanwhile the FCF had the freezing time and rate of $360 \mathrm{~min}$ and $6.67{ }^{\circ} \mathrm{C} \mathrm{h}^{-1}$.

Drip loss is defined as the loss of weight after thawing (Boonsumrej et al., 2007), and considered to be the major problem of frozen fishery products (Rao \& Novak, 1977). Lower drip loss means that the formation of ice crystals was smaller in the samples, which is beneficial to maintain the quality (Anese et al., 2012). Under disparate freezing rates, drip loss differed significantly during the frozen storage (Figure 2). In particular, FCF had significantly higher drip loss (0.96-2.27\%) than those of cryogenic freezing at $-40,-60$ and $-80^{\circ} \mathrm{C}(0.72-2.09 \%)$ (Figure 2). Drip loss of cryogenic freezing at $-60{ }^{\circ} \mathrm{C}$ at 0,3 and 6-month were significantly lower than the two other cryogenic freezing temperature (Figure 2).

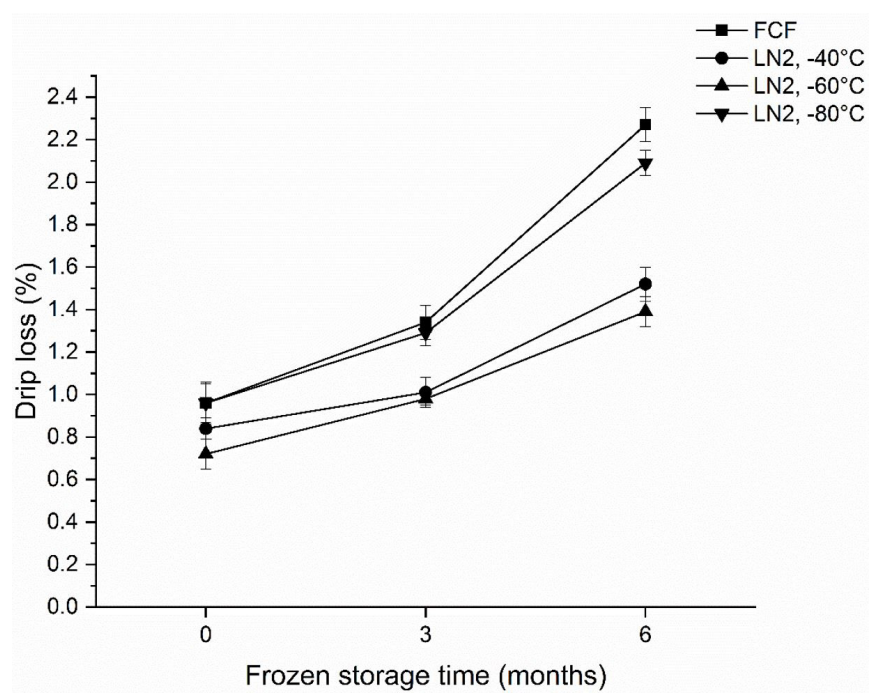

Figure 2. Drip loss (\%) of liquid nitrogen $\left(\mathrm{LN}_{2}\right)$ and forced convection freezing $(\mathrm{FCF})$ of large yellow croaker in storage duration. 
Freezing temperature/rate can affect the drip loss during thawing of fish products (Añón \& Calvelo, 1980; Hiner et al., 1945; Espinoza Rodezno et al., 2013). At low freezing rate, large interfibrillar crystals develop and push the muscle fibers into irregular groups, that water loss during thawing cannot be reabsorbed through the muscle membrane (Añón \& Calvelo, 1980). As the freezing rate increases, smaller ice crystals grow at the expense of intracellular water that can interact again with the muscle protein after thawing (Añón \& Calvelo, 1980). Therefore, freezing temperature/rate is the key factor that should be controlled in the freezing process of fish products.

In some studies, however, once the freezing rate continues to increase, the proportion of ice frozen within the fiber will be too high, presumably rupturing the fiber tissues (Hiner et al., 1945). This is particularly true in studies employing lower cryogenic freezing temperature (liquid nitrogen at $-120^{\circ} \mathrm{C}$ ), which showed surface cracking and bigger bundle spacing between muscle fibers of frozen grass shrimp, compared to higher cryogenic freezing temperature $\left(-80\right.$ and $\left.-100{ }^{\circ} \mathrm{C}\right)$ (Pan \& Yeh, 1993). Therefore, it is vital to utilize proper temperatures but froze the samples.

\subsection{Moisture content and Relative Moisture Loss (RML)}

Moisture contents of the samples subjected to cryogenic freezing at $-40{ }^{\circ} \mathrm{C}$ and FCF decreased significantly after six months of storage (Table 1). In addition, moisture contents of cryogenic freezing at $-80{ }^{\circ} \mathrm{C}$ also decreased slightly, but it did not differ significantly after cryogenic freezing at $-60{ }^{\circ} \mathrm{C}$ $(P>0.05$, Table 1$)$. Similar to our results, Espinoza Rodezno et al. (2013) also found that cryogenic freezing of catfish fillets had only slight decrease in moisture content after six months of frozen storage (cryogenic freezing).

Moreover, the moisture content of fish samples subjected to cryogenic freezing at $-60{ }^{\circ} \mathrm{C}$ were significantly higher than other freezing procedure during the frozen storage $(P<0.05$, Table 1), whilst FCF obtained the lowest moisture content than those of other freezing procedure $(P<0.05$, Table 1$)$. These results supported that cryogenic freezing can help to hold water in the fish muscle or fillets.

After convection or cryogenic freezing, there was an increase in the relative moisture loss of large yellow croaker through the frozen storage time (Figure 3). Moreover, different freezing treatments in our study (convection or cryogenic freezing) resulted in different relative moisture loss of large yellow croaker muscle (see Figure 3). The cryogenic freezing at $-60{ }^{\circ} \mathrm{C}$ obtained the lowest RML values and the FCF had the highest RML (Figure 3 ). Nevertheless, the RML of cryogenic freezing was not significantly different as compared to air blast freezing after six months of frozen storage (Espinoza Rodezno et al., 2013).

\subsection{Water holding capacity}

The WHC of large yellow croaker at different freezing treatments displayed a decreasing trend over the frozen storage time (Figure 4). The WHC of all freezing treatments did not differ significantly at 0 -month, but began to differentiate after three months storage. At 6-month, the WHC values declined drastically in all treatments; moreover, FCF expressed lowest value.

Water holding capacity can be correlated to sensory attributes of fish muscle (Jensen \& Jørgensen, 1997) and can easily be affected by freezing injury resulting from phase transition of water in muscle fibers (Ueng \& Chow, 1998). The WHC values in the present study decreased over the frozen storage and this mirrored with previous studies (Apata, 2014; Gokoglu et al., 2018). The decrease in WHC can cause the unacceptable WHC in meat products (Huff-Lonergan \& Lonergan, 2005; Lan et al., 2016). In our study, the cryogenic freezing was observed to have the higher WHC values than those of FCF (Figure 4). This might be related to the higher shear force of cryogenic freezing at $-60^{\circ} \mathrm{C}$ at 6-month, compared to other freezing treatments.

\subsection{Color}

Skin color is another vital parameter in judging the physiological, behavioral, sensory attributes and acceptability of fish products (Pavlidis et al., 2006). Large yellow croaker is a marine fish with uniquely particular yellow skin color (Guo et al., 2018).

There were no significant differences in the values of $\mathrm{L}^{*}, \mathrm{a}^{*}, \mathrm{~b}^{*}$ irrespective of freezing treatments when samples were tested

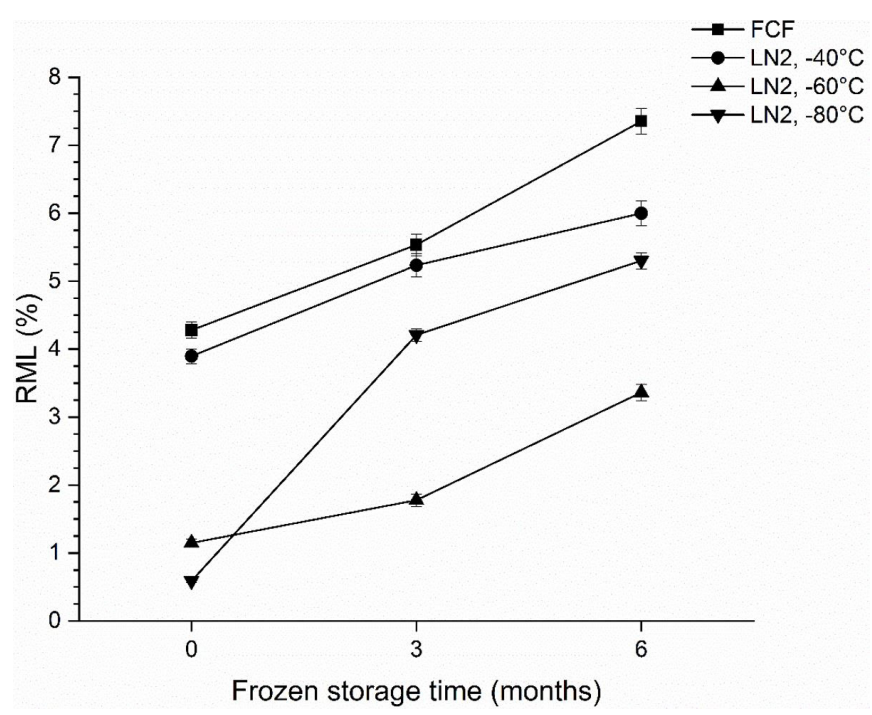

Figure 3. Relative moisture loss (\%) of liquid nitrogen $\left(\mathrm{LN}_{2}\right)$ and forced convection freezing (FCF) of large yellow croaker in storage duration.

Table 1. Moisture content (g/100 g, wet basic) in large yellow croaker muscle by liquid nitrogen (LN2) and forced convection freezing (FCF).

\begin{tabular}{ccccc}
\hline Moisture content $(\mathrm{g} / 100 \mathrm{~g})$ & FCF & $\mathrm{LN}_{2},-40^{\circ} \mathrm{C}$ & $\mathrm{LN}_{2},-60^{\circ} \mathrm{C}$ & $\mathrm{LN}_{2},-80^{\circ} \mathrm{C}$ \\
\hline 0-month & $70.04 \pm 0.70^{\mathrm{aA}}$ & $70.32 \pm 1.09^{\mathrm{aA}}$ & $72.33 \pm 0.79^{\mathrm{bA}}$ & $72.74 \pm 1.20^{\mathrm{bA}}$ \\
3-month & $69.12 \pm 1.11^{\mathrm{aA}}$ & $69.34 \pm 0.64^{\mathrm{aA}}$ & $71.87 \pm 0.92^{\mathrm{bA}}$ & $70.09 \pm 0.87^{\mathrm{aB}}$ \\
6-month & $67.79 \pm 0.92^{\mathrm{aB}}$ & $68.78 \pm 1.28^{\mathrm{aA}}$ & $70.71 \pm 1.23^{\mathrm{bA}}$ & $69.29 \pm 1.44^{\mathrm{abB}}$ \\
\hline
\end{tabular}

Means with different letters $(\mathrm{ab})$ in the same row are significantly different for different freezing treatments $(\mathrm{p}<0.05)$; means with different letters $(\mathrm{AB})$ in the same column are significantly different in the frozen storage time $(\mathrm{p}<0.05)$. 
immediately after freezing; however, $\mathrm{a}^{*}$ values of cryogenic freezing at -60 and $-80^{\circ} \mathrm{C}$ were higher than cryogenic freezing at $-40^{\circ} \mathrm{C}$ and FCF (Table 2).

During the frozen storage, the $\mathrm{L}^{*}$ values of FCF decreased, whilst those of the cryogenic freezing -40 and $-60{ }^{\circ} \mathrm{C}$ showed a slight increase (Table 2). At the end of 6-month storage, the samples subjected to cryogenic freezing had higher $\mathrm{L}^{*}$ values compared to FCF (Table 2). In addition, $\mathrm{a}^{\star}$ values decreased throughout the storage time for the FCF and cryogenic freezing at $-40{ }^{\circ} \mathrm{C}$. At 6 -month, $\mathrm{a}^{*}$ values of frozen fishes subjected to cryogenic freezing at -60 and $-80{ }^{\circ} \mathrm{C}$ still remained high, meanwhile $\mathrm{a}^{*}$ values of cryogenic frozen fishes at $-40{ }^{\circ} \mathrm{C}$ and FCF plummeted (Table 2). Moreover, the cryogenic freezing at $-40{ }^{\circ} \mathrm{C}$ and FCF had a sharp decline in $\mathrm{b}^{*}$ values at 6-month, while cryogenic freezing at -60 and $-80{ }^{\circ} \mathrm{C}$ had the minimal decline tendency of $b^{\star}$ values.

Generally, the $\mathrm{L}^{*}$ and $\mathrm{b}^{*}$ values of large yellow croaker markedly decreased during frozen storage, and $a^{*}$ value significantly increased (Table 2). At 6-month, the lower values of $\mathrm{L}^{*}$ and $\mathrm{b}^{*}$ could be observed in the samples of FCF compared to those observed in cryogenic freezing of large yellow croaker.

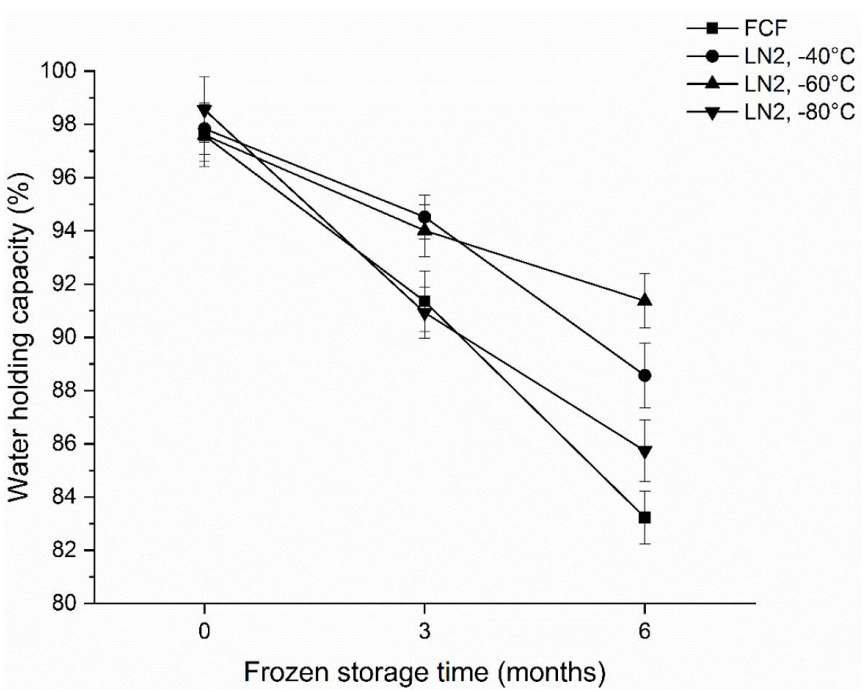

Figure 4. Water holding capacity of liquid nitrogen $\left(\mathrm{LN}_{2}\right)$ and forced convection freezing (FCF) of large yellow croaker in storage duration.
In terms of cryogenic freezing, the color parameters of large yellow croaker samples did not differ significantly in the first three months of frozen storage. At 6-month, $\mathrm{L}^{\star}$ value continued to have non-significant difference in cryogenic treatments; and higher $\mathrm{a}^{*}$ and $\mathrm{b}^{*}$ values were observed in cryogenic freezing at -60 and $-80{ }^{\circ} \mathrm{C}$, compared to $-40{ }^{\circ} \mathrm{C}$. From these results, it appears that cryogenic freezing at different freezing temperature does not have any effects on large yellow croaker skin color at least until 6 months.

Up to date, there has been few studies addressing the effect of cryogenic freezing on the skin color of fish (Espinoza Rodezno et al., 2013; Sheehan et al., 1998). In catfish fillets, Espinoza Rodezno et al. (2013) observed higher L* during cryogenic freezing compared to air-blast freezing. Moreover, $\mathrm{a}^{\star}$ and $\mathrm{b}^{*}$ values were reported not to be affected by different freezing methods in the research about the catfish fillets under air-blast and cryogenic freezing (Espinoza Rodezno et al., 2013). Similarly, Sheehan et al. (1998) also showed that a* value of raw Atlantic salmon (Salmo salar) flesh increased from 6 weeks to 12 weeks during frozen storage at $-20{ }^{\circ} \mathrm{C}$, although those authors did not find a significant change in carotenoid content of astaxanthin-fed fish after frozen storage for 6 and 12 weeks. The results of all these studies indicate that there is no change in skin color during cryogenic freezing.

\subsection{Texture}

Texture profile of fish can vary depending on the fish species and storage duration (Hashimoto et al., 2016; Hernández et al., 2009; Skjervold et al., 2001). In this study, texture profile of large yellow croaker was measured by cohesiveness, springiness, gumminess, chewiness and shear force values (Table 3).

The cohesiveness values of large yellow croaker in FCF dropped immediately after freezing, and continued to decline until 6 months (Table 3). Meanwhile, cohesiveness values of cryogenic freezing at -60 and $-80{ }^{\circ} \mathrm{C}$ remained stable, but increased at the end of six months storage. Moreover, the cohesiveness showed higher values in cryogenic freezing at -60 and $-80^{\circ} \mathrm{C}$, compared to FCF (Table 3). In contrast to our findings, Jiang et al. (2018) reported that freezing methods (liquid nitrogen or ultra-low-temperature freezer) did not significantly affect the cohesiveness values of northern snakehead during five months' storage.

Table 2. Color profile of large yellow croaker by liquid nitrogen $\left(\mathrm{LN}_{2}\right)$ and forced convection freezing (FCF).

\begin{tabular}{|c|c|c|c|c|c|}
\hline & Time & FCF & $\mathrm{LN}_{2},-40^{\circ} \mathrm{C}$ & $\mathrm{LN}_{2},-60{ }^{\circ} \mathrm{C}$ & $\mathrm{LN}_{2},-80^{\circ} \mathrm{C}$ \\
\hline \multirow[t]{3}{*}{$\mathrm{L}^{*}$} & 0 -month & $67.64 \pm 1.15^{\mathrm{aA}}$ & $67.74 \pm 2.78^{\mathrm{aA}}$ & $65.99 \pm 5.24^{\mathrm{aA}}$ & $71.38 \pm 3.07^{a A}$ \\
\hline & 3-month & $69.17 \pm 0.75 \mathrm{abA}$ & $67.09 \pm 1.45^{\mathrm{aA}}$ & $69.44 \pm 1.58^{\text {аьв }}$ & $71.48 \pm 2.58^{b}$ \\
\hline & 6-month & $64.94 \pm 1.84 \mathrm{aB}$ & $71.27 \pm 0.63^{\text {ьв }}$ & $71.20 \pm 0.92^{\text {ьв }}$ & $71.54 \pm 1.96^{b}$ \\
\hline \multirow[t]{3}{*}{$a^{*}$} & 0 -month & $4.66 \pm 0.18^{\mathrm{aA}}$ & $6.45 \pm 0.49^{\mathrm{abA}}$ & $8.27 \pm 0.54^{\mathrm{bA}}$ & $7.27 \pm 2.22^{b-}$ \\
\hline & 3-month & $4.79 \pm 0.28^{\mathrm{aA}}$ & $5.19 \pm 0.14^{\text {ьв }}$ & $6.92 \pm 0.17^{\mathrm{cB}}$ & $6.82 \pm 0.22^{\mathrm{cA}}$ \\
\hline & 6-month & $3.84 \pm 0.15^{\mathrm{aB}}$ & $2.75 \pm 0.27 \mathrm{bC}$ & $7.71 \pm 0.19^{\mathrm{cA}}$ & $7.06 \pm 0.32 \mathrm{~d}$ \\
\hline \multirow[t]{3}{*}{$b^{*}$} & 0 -month & $43.77 \pm 2.87^{\mathrm{aA}}$ & $37.27 \pm 3.86^{\mathrm{aA}}$ & $39.48 \pm 4.82^{\mathrm{aA}}$ & $40.62 \pm 1.86^{\mathrm{a} A}$ \\
\hline & 3-month & $37.12 \pm 0.65^{\mathrm{aB}}$ & $45.22 \pm 1.63^{\mathrm{bB}}$ & $41.01 \pm 1.78^{\mathrm{bA}}$ & $45.98 \pm 0.75$ \\
\hline & 6-month & $32.26 \pm 0.96^{\mathrm{aC}}$ & $31.93 \pm 1.72^{\mathrm{aC}}$ & $37.20 \pm 2.62^{\mathrm{bA}}$ & $39.13 \pm 0.85^{\mathrm{cA}}$ \\
\hline
\end{tabular}

$L^{*}, a^{*}, b^{*}$ express the lightness, redness and yellowness of large yellow croaker skin color $\left(L^{*}, a^{*}, b^{*}>0\right)$. Means with different letters (abcd) in the same row are significantly different for different freezing treatments $(\mathrm{p}<0.05)$; means with different letters $(\mathrm{ABC})$ in the same column are significantly different in the frozen storage time $(\mathrm{p}<0.05)$. 
Table 3. Texture profile of large yellow croaker by liquid nitrogen $\left(\mathrm{LN}_{2}\right)$ and forced convection freezing (FCF).

\begin{tabular}{|c|c|c|c|c|c|}
\hline Texture & Time & FCF & $\mathrm{LN}_{2},-40^{\circ} \mathrm{C}$ & $\mathrm{LN}_{2},-60^{\circ} \mathrm{C}$ & $\mathrm{LN}_{2},-80^{\circ} \mathrm{C}$ \\
\hline \multirow[t]{3}{*}{ Cohesiveness } & 0 -month & $0.18 \pm 0.03^{\mathrm{aAB}}$ & $0.23 \pm 0.02^{\mathrm{bA}}$ & $0.23 \pm 0.03^{\mathrm{bA}}$ & $0.22 \pm 0.02^{\mathrm{abA}}$ \\
\hline & 3-month & $0.23 \pm 0.02^{\mathrm{aA}}$ & $0.25 \pm 0.01^{\mathrm{bA}}$ & $0.21 \pm 0.02^{\mathrm{cB}}$ & $0.21 \pm 0.01^{\mathrm{cA}}$ \\
\hline & 6-month & $0.16 \pm 0.01 \mathrm{aB}$ & $0.18 \pm 0.02^{\mathrm{abB}}$ & $0.21 \pm 0.03^{\text {ьв }}$ & $0.20 \pm 0.03^{\mathrm{abA}}$ \\
\hline \multirow[t]{3}{*}{ Springiness $(\mathrm{mm})$} & 0 -month & $1.16 \pm 0.17^{\mathrm{aA}}$ & $1.57 \pm 0.21^{\mathrm{aA}}$ & $1.61 \pm 0.57^{\mathrm{aA}}$ & $1.53 \pm 0.25^{\mathrm{aA}}$ \\
\hline & 3-month & $1.75 \pm 0.43^{\mathrm{aAB}}$ & $1.75 \pm 0.16^{\mathrm{aAB}}$ & $1.81 \pm 0.13^{\mathrm{aA}}$ & $1.56 \pm 0.12^{\mathrm{aA}}$ \\
\hline & 6-month & $2.10 \pm 0.52^{\mathrm{aB}}$ & $1.90 \pm 0.09$ abB & $1.99 \pm 0.18^{\mathrm{aA}}$ & $1.34 \pm 0.27^{\mathrm{bA}}$ \\
\hline \multirow[t]{3}{*}{ Gumminess (N) } & 0 -month & $4.14 \pm 1.14^{\mathrm{aA}}$ & $4.46 \pm 1.13^{\mathrm{aA}}$ & $5.40 \pm 1.21^{\mathrm{aA}}$ & $4.40 \pm 1.14^{\mathrm{aA}}$ \\
\hline & 3-month & $4.39 \pm 0.97^{\mathrm{aA}}$ & $2.91 \pm 0.72^{\mathrm{bA}}$ & $3.84 \pm 0.98^{\mathrm{abA}}$ & $4.41 \pm 0.92^{\mathrm{aA}}$ \\
\hline & 6-month & $1.72 \pm 0.39$ ав & $2.82 \pm 1.69^{\mathrm{abA}}$ & $3.62 \pm 0.95^{\mathrm{bA}}$ & $1.70 \pm 0.42^{\mathrm{aB}}$ \\
\hline \multirow[t]{3}{*}{ Chewiness (mJ) } & 0 -month & $7.22 \pm 0.23^{\mathrm{aA}}$ & $7.30 \pm 0.65^{\mathrm{aA}}$ & $9.62 \pm 0.97 \mathrm{bA}$ & $6.85 \pm 0.79^{\mathrm{aA}}$ \\
\hline & 3-month & $4.98 \pm 0.86^{\mathrm{aB}}$ & $6.88 \pm 2.33^{\mathrm{aA}}$ & $6.04 \pm 1.68^{\mathrm{aB}}$ & $6.70 \pm 1.81^{\mathrm{aA}}$ \\
\hline & 6-month & $4.64 \pm 0.23 \mathrm{aB}$ & $6.01 \pm 0.98^{\mathrm{bA}}$ & $6.98 \pm 0.45^{\text {ьв }}$ & $5.10 \pm 0.79 \mathrm{aA}$ \\
\hline \multirow[t]{3}{*}{ Shear force $(\mathrm{N})$} & 0 -month & $7.82 \pm 2.60^{\mathrm{aA}}$ & $7.66 \pm 0.88^{\mathrm{aA}}$ & $8.26 \pm 2.32^{\mathrm{aA}}$ & $7.75 \pm 1.83^{\mathrm{aA}}$ \\
\hline & 3-month & $5.86 \pm 1.76^{\mathrm{aA}}$ & $6.05 \pm 1.51^{\mathrm{aA}}$ & $6.05 \pm 1.50^{\mathrm{aA}}$ & $7.56 \pm 1.22 \mathrm{aA}$ \\
\hline & 6-month & $5.46 \pm 0.11 \mathrm{aB}$ & $5.72 \pm 1.23^{\mathrm{abB}}$ & $7.20 \pm 0.79^{\mathrm{bA}}$ & $5.98 \pm 1.08^{\mathrm{bB}}$ \\
\hline
\end{tabular}

Means with different letters $(\mathrm{abc})$ in the same row are significantly different for different freezing treatments $(\mathrm{p}<0.05)$; means with different letters $(\mathrm{AB})$ in the same column are significantly different in the frozen storage time $(\mathrm{p}<0.05)$.

We found no significant differences in the springiness, gumminess and chewiness between cryogenic and FCF in the first three months of storage (Table 3). This finding is in accordance with the texture profile parameters of octopus (Octopus vulgaris), that non-significant differences in springiness, gumminess and chewiness during the frozen storage at $-18^{\circ} \mathrm{C}$ for 30 days have been reported (Gokoglu et al., 2018). Collectively, these results point to the possibility that that large yellow croaker has special textural characteristics as noted in octopus. However, this suggestion warrants further in-depth study. Nevertheless, after 6 months of frozen storage, our results indicate a higher chewiness values of large yellow croaker in cryogenic freezing at -40 and $-60^{\circ} \mathrm{C}$ (except for $-80^{\circ} \mathrm{C}$ ). Similar to our study, the ultra-low temperature $\left(-80^{\circ} \mathrm{C}\right)$ and liquid nitrogen immersion freezing significantly affected the chewiness of northern snakehead when stored at $-20^{\circ} \mathrm{C}$ for five months (Jiang et al., 2018).

Shear forces values of cryogenic and FCF did not differ significantly at 0 and 3 -month (Table 3 ). This trend was similar to the cryogenic and air-blast freezing of chicken fryer halves (Streeter \& Spencer, 1973). However, at 6-month, the shear force values of FCF and cryogenic at -40 and $-80^{\circ} \mathrm{C}$ decreased, reflecting the toughness of the samples (Table 3 ). This may be due to the enzymatic and bacterial activities that can decompose muscle proteins (Lan et al., 2016). Additionally, the phase transition of ice to water can lead to softer muscles and reduces the force use to shear fish muscle (Leygonie et al., 2012). Compared to other treatments, shear force value cryogenic freezing at $-60^{\circ} \mathrm{C}$ remained high after 6 months $(7.20 \pm 0.79 \mathrm{~N})$ (Table 3 ). It showed the potential of cryogenic freezing at $-60^{\circ} \mathrm{C}$ for long-term storage of large yellow croaker.

\section{Conclusion}

In conclusion, this study showed that frozen storage by employing cryogenic freezing at $-60^{\circ} \mathrm{C}$ and subsequently storing it at $-18^{\circ} \mathrm{C}$ resulted in better quality of large yellow croaker after 6 months than that of the FCF. However, cryogenic freezing at different freezing temperatures produced variations in product quality. At 6-month, cryogenic freezing at -60 and $-80^{\circ} \mathrm{C}$ had the highest yellowness values. The cryogenic freezing at $-60^{\circ} \mathrm{C}$ showed the superior texture profile with significantly higher values of springiness, gumminess and shear force in storage duration. Yet, further studies are deemed essential to understand the rationale behind the mechanisms on how cryogenic freezing affects large yellow croaker fillet by specifically focusing on water migration, ice crystals formation, microstructure of fish muscle, lipid oxidation and sensory modification in storage duration.

\section{Acknowledgements}

We are grateful to Ningde Jingli Aquatic Products Co., Ltd. for suppling the fish materials. Praxair Technology Project (Shanghai, China), Grant/Award Number: No. 3A308014.

\section{References}

Agnelli, M. E., \& Mascheroni, R. H. (2002). Quality evaluation of foodstuffs frozen in a cryomechanical freezer. Journal of Food Engineering, 52(3), 257-263. http://dx.doi.org/10.1016/S0260-8774(01)00113-3.

Anese, M., Manzocco, L., Panozzo, A., Beraldo, P., Foschia, M., \& Nicoli, M. C. (2012). Effect of radiofrequency assisted freezing on meat microstructure and quality. Food Research International, 46(1), 50-54. http://dx.doi.org/10.1016/j.foodres.2011.11.025.

Añón, M. C., \& Calvelo, A. (1980). Freezing rate effects on the drip loss of frozen beef. Meat Science, 4(1), 1-14. http://dx.doi.org/10.1016/03091740(80)90018-2. PMid:22055482.

Apata, E. S. (2014). Effects of postmortem processing and freezing on water holding capacity, water bratzler value and chemical composition of Chevon. American Journal of Research Communication, 2, 100-113.

Boonsumrej, S., Chaiwanichsiri, S., Tantratian, S., Suzuki, T., \& Takai, R. (2007). Effects of freezing and thawing on the quality changes of tiger shrimp (Penaeus monodon) frozen by air-blast and cryogenic freezing. Journal of Food Engineering, 80(1), 292-299. http://dx.doi. org/10.1016/j.jfoodeng.2006.04.059. 
Campañone, L. A., Salvadori, V. O., \& Mascheroni, R. H. (2001). Weight loss during freezing and storage of unpackaged foods. Journal of Food Engineering, 47(2), 69-79. http://dx.doi.org/10.1016/S02608774(00)00101-1.

Chen, Y. L., \& Pan, B. S. (1997). Morphological changes in tilapia muscle following freezing by airblast and liquid nitrogen methods. International Journal of Food Science \& Technology, 32(2), 159-168. http://dx.doi.org/10.1046/j.1365-2621.1997.00392.x.

China National Standards - GB. (2016). China national food safety standard. Shenzhen: GP. Retrieved from http://down.foodmate. net/standard/allcategory.html

Espinoza Rodezno, L. A., Sundararajan, S., Solval, K. M., Chotiko, A., Li, J., Zhang, J., Alfaro, L., Bankston, J. D., \& Sathivel, S. Rodezno, L. A. E., Sundararajan, S., Solval, K. M., Chotiko, A., Li, J., Zhang, J., \& Sathivel, S. (2013). Cryogenic and air blast freezing techniques and their effect on the quality of catfish fillets. Lebensmittel-Wissenschaft + Technologie, 54(2), 377-382. http://dx.doi.org/10.1016/j.lwt.2013.07.005.

Gokoglu, N., Topuz, O. K., Yerlikaya, P., Yatmaz, H. A., \& Ucak, I. (2018). Effects of freezing and frozen storage on protein functionality and texture of some cephalopod muscles. Journal of Aquatic Food Product Technology, 27(2), 211-218. http://dx.doi.org/10.1080/104 98850.2017.1422168.

Guo, Q., Truonghuynh, T., Jiang, C., Wang, L., Li, B., \& Xing, X. (2018). Quality differences of large yellow croaker (pseudosciaena crocea) cultured in deep-water sea cages of two China regions. Journal of Aquaculture Research \& Development, 9(9), 1-8. http://dx.doi. org/10.4172/2155-9546.1000547.

Guo, Y., \& Zhao, W. (2017). China fishery statistical yearbook. China: Fisheries Agency of China Agriculture Ministry.

Hashimoto, K., Kobayashi, S., \& Yamashita, M. (2016). Comparison of connective tissue structure and muscle toughness of spotted mackerel Scomber australasicus and Pacific mackerel S. japonicus during chilled and frozen storage. Fisheries Science, 83(1), 133-139. http://dx.doi.org/10.1007/s12562-016-1042-4.

Hernández, M. D., López, M. B., Álvarez, A., Ferrandini, E., García García, B., \& Garrido, M. D. (2009). Sensory, physical, chemical and microbiological changes in aquacultured meagre (Argyrosomus regius) fillets during ice storage. Food Chemistry, 114(1), 237-245. http://dx.doi.org/10.1016/j.foodchem.2008.09.045.

Hiner, R. L., Madsen, L. L., \& Hankins, O. G. (1945). Histological characteristics, tenderness, and drip losses of beef in relation to temperature of freezing. Food Research, 10(4), 312-324. http://dx.doi. org/10.1111/j.1365-2621.1945.tb16173.x.

Huff-Lonergan, E., \& Lonergan, S. M. (2005). Mechanisms of waterholding capacity of meat: the role of postmortem biochemical and structural changes. Meat Science, 71(1), 194-204. http://dx.doi. org/10.1016/j.meatsci.2005.04.022. PMid:22064064.

Jensen, H. S., \& Jørgensen, B. M. (1997). A sensometric approach to cod-quality measurement. Food Quality and Preference, 8(5-6), 403407. http://dx.doi.org/10.1016/S0950-3293(97)00029-3.

Jiang, Q., Okazaki, E., Zheng, J., Que, T., Chen, S., \& Hu, Y. (2018). Structure of northern snakehead (Channa argus) meat: effects of freezing method and frozen storage. International Journal of Food Properties, 1(1), 1166-1179. http://dx.doi.org/10.1080/10942912.2 018.1437631.

Kono, S., Kon, M., Araki, T., \& Sagara, Y. (2017). Effects of relationships among freezing rate, ice crystal size and color on surface color of frozen salmon fillet. Journal of Food Engineering, 214, 158-165. http://dx.doi.org/10.1016/j.jfoodeng.2017.06.023.

Lan, Y., Shang, Y., Song, Y., \& Dong, Q. (2016). Changes in the quality of superchilled rabbit meat stored at different temperatures. Meat
Science, 117, 173-181. http://dx.doi.org/10.1016/j.meatsci.2016.02.017. PMid:26990070.

Leygonie, C., Britz, T. J., \& Hoffman, L. C. (2012). Meat quality comparison between fresh and frozen/thawed ostrich M. iliofibularis. Meat Science, 91(3), 364-368. http://dx.doi.org/10.1016/j.meatsci.2012.02.020. PMid:22405875.

Liu, M., Mitcheson, D., \& Sadovy, Y. (2008). Profile of a fishery collapse: why mariculture failed to save the large yellow croaker. Fish and Fisheries, 9(3), 219-242. http://dx.doi.org/10.1111/j.14672979.2008.00278.X.

Luan, L., Sun, Y., Chen, S., Wu, C., \& Hu, Y. (2018). A study of fractal dimension as a quality indicator of hairtail (Trichiurus haumela) samples during frozen storage. Scientific Reports, 8(1), 164-168. http://dx.doi.org/10.1038/s41598-018-33880-3. PMid:30405181.

Makarios-Laham, I. K., \& Lee, T. C. (1993). Protein hydrolysis and quality deterioration of refrigerated and frozen seafood due to obligately psychrophilic bacteria. Journal of Food Science, 58(2), 310-313. http://dx.doi.org/10.1111/j.1365-2621.1993.tb04263.x.

Mørkøre, T., \& Lilleholt, R. (2007). Impact of freezing temperature on quality of farmed Atlantic cod (Gadus morhua L.). Journal of Texture Studies, 38(4), 457-472. http://dx.doi.org/10.1111/j.17454603.2007.00108.x.

Pan, B. S., \& Yeh, W.-T. (1993). Biochemical and morphological changes in grass shrimp (Penaeus monodon) muscle following freezing by air blast and liquid nitrogen methods. Journal of Food Biochemistry, 17(3), 147-160. http://dx.doi.org/10.1111/j.1745-4514.1993.tb00464.x.

Pavlidis, M., Papandroulakis, N., \& Divanach, P. (2006). A method for the comparison of chromaticity parameters in fish skin: preliminary results for coloration pattern of red skin Sparidae. Aquaculture, 258(14), 211-219. http://dx.doi.org/10.1016/j.aquaculture.2006.05.028.

Qian, P., Zhang, Y., Shen, Q., Ren, L., Jin, R., Xue, J., Yao, H., \& Dai, Z. (2018). Effect of cryogenic immersion freezing on quality changes of vacuum-packed bighead carp (Aristichthys nobilis) during frozen storage. Journal of Food Processing and Preservation, 42(6), 1-7. http://dx.doi.org/10.1111/jfpp.13640.

Rao, R. M., \& Novak, A. F. (1977). Causes and prevention of weight losses in frozen fishery products during freezing and cold storage. Proceedings of the Gulf and Caribbean Fisheries Institute, 29, 28-42.

Sheehan, E. M., O’Connor, T. P., Sheehy, P. J. A., Buckley, D. J., \& FitzGerald, R. (1998). Stability of astaxanthin and canthaxanthin in raw and smoked Atlantic salmon (Salmo salar) during frozen storage. Food Chemistry, 63(3), 313-317. http://dx.doi.org/10.1016/ S0308-8146(98)00048-X.

Skjervold, P. O., Bencze Rørå, A. M., Fjæra, S. O., Vegusdal, A., Vorre, A., \& Einen, O. (2001). Effects of pre-, in-, or post-rigor filleting of live chilled Atlantic salmon. Aquaculture, 194(3-4), 315-326. http:// dx.doi.org/10.1016/S0044-8486(00)00531-7.

Streeter, E. M., \& Spencer, J. V. (1973). Cryogenic and conventional freezing of chicken. Poultry Science, 52(1), 317-325. http://dx.doi. org/10.3382/ps.0520317.

Tolstorebrov, I., Eikevik, T. M., \& Bantle, M. (2016). Effect of low and ultra-low temperature applications during freezing and frozen storage on quality parameters for fish. International Journal of Refrigeration, 63, 37-47. http://dx.doi.org/10.1016/j.ijrefrig.2015.11.003.

Ueng, Y.-E., \& Chow, C.-J. (1998). Textural and histological changes of different squid mantle muscle during frozen storage. Journal of Agricultural and Food Chemistry, 46(11), 4728-4733. http://dx.doi. org/10.1021/jf9803278.

Wagner, J. R., \& Anon, M. C. (1985). Effect of freezing rate on the denaturation of myofibrillar proteins. International Journal of Food Science \& Technology, 20(6), 735-744. http://dx.doi. org/10.1111/j.1365-2621.1985.tb01971.x. 